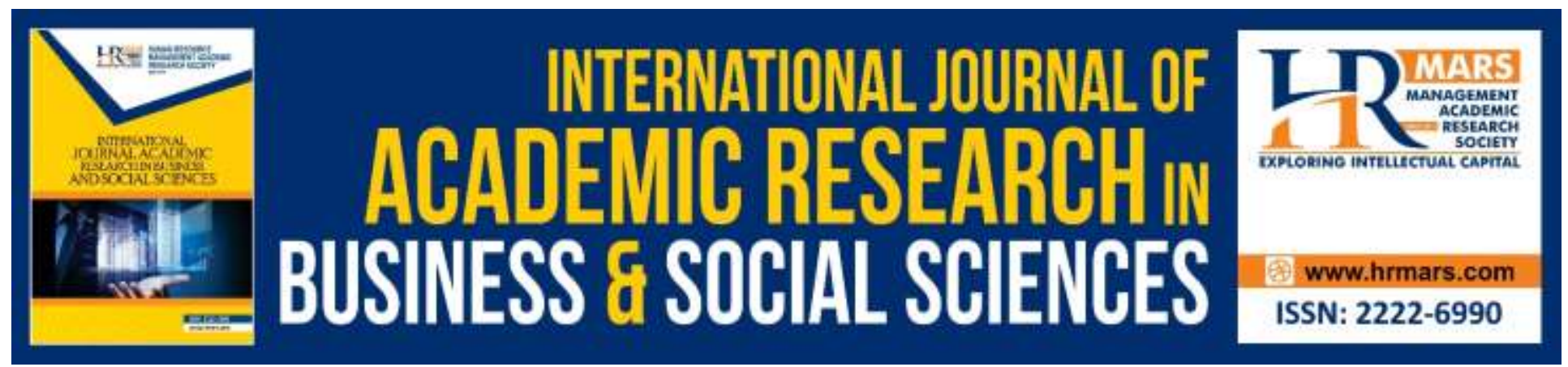

\title{
Learning Challenges to Inclusive Learning in an ECDE Centers in Eldoret East Sub-County, Uasin Gishu County, Kenya
}

Hellen Kiplagat, Justina Syonthi, Julia Situma

To Link this Article: http://dx.doi.org/10.6007/IJARBSS/v9-i11/6572

DOI: 10.6007/IJARBSS/v9-i11/6572

Received: 12 October 2019, Revised: 28 October 2019, Accepted: 05 November 2019

Published Online: 26 November 2019

In-Text Citation: (Kiplagat, Syonthi, \& Situma, 2019)

To Cite this Article: Kiplagat, H., Syonthi, J., Situma, J. (2019). Learning Challenges to Inclusive Learning in an ECDE Centres in Eldoret East Sub-County, Uasin Gishu County, Kenya. International Journal of Academic Research in Business and Social Sciences, 9(11), 513-535.

Copyright: (c) 2019 The Author(s)

Published by Human Resource Management Academic Research Society (www.hrmars.com)

This article is published under the Creative Commons Attribution (CC BY 4.0) license. Anyone may reproduce, distribute, translate and create derivative works of this article (for both commercial and non-commercial purposes), subject to full attribution to the original publication and authors. The full terms of this license may be seen

at: $\underline{\text { http://creativecommons.org/licences/by/4.0/legalcode }}$

\section{Vol. 9, No. 11, 2019, Pg. 513 - 535}

Full Terms \& Conditions of access and use can be found at http://hrmars.com/index.php/pages/detail/publication-ethics 


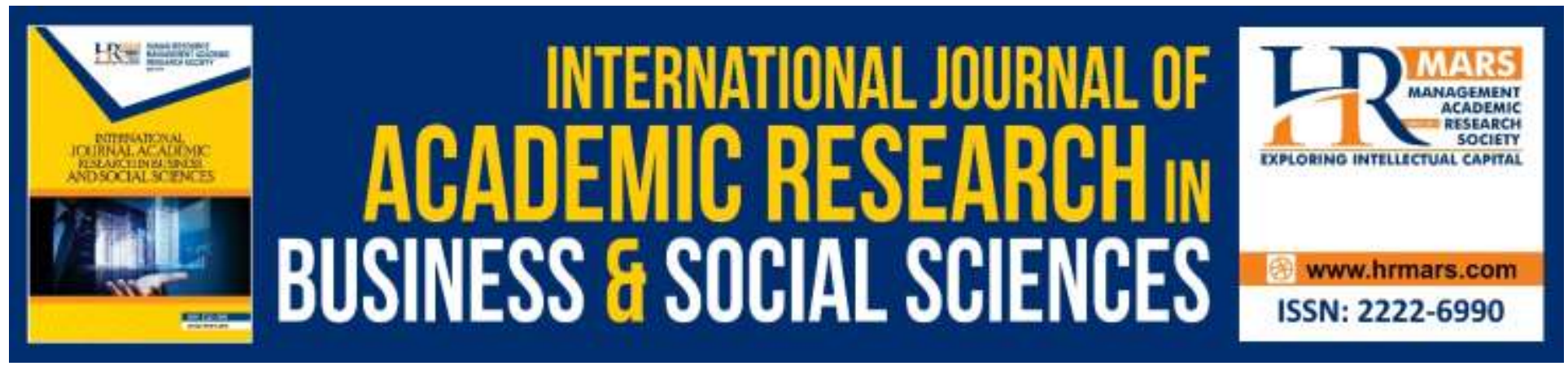

\title{
Learning Challenges to Inclusive Learning in an ECDE Centers in Eldoret East Sub-County, Uasin Gishu County, Kenya
}

\author{
${ }^{1}$ Hellen Kiplagat, ${ }^{2}$ Dr. Justina Syonthi, ${ }^{3}$ Dr. Julia Situma \\ ${ }^{1}$ Master's Degree in the Department of Early Childhood School of Education and Human \\ Resource Development, ${ }^{2}$ Kisii University, Kenya, ${ }^{3}$ Kisii University, Kenya
}

\begin{abstract}
Education is increasingly gaining prominence as one of the most important subjects in Africa, with emphasis being put on special needs education. Inclusion of hearing and visually impaired as well as the physically challenged children into regular learning environment is still a controversial issue. The success of inclusion programs is dependent on many factors. The purpose of this study was to find out the learning challenges to inclusive learning in Early Childhood Development Education (ECDE) in Eldoret East Sub-County, Uasin Gishu County, Kenya. The study was conducted in public ECDE centers' in Eldoret East Sub-County, Uasin Gishu County, Kenya. The study was guided by the Social Model of Disability Definition. The study used descriptive survey research design which involved collection of views, opinions, attitude, and suggestions. The study target population was 260 respondents, thus sample 85 respondents, including 1 TSC Sub County Director of education, 9 Curriculum support officers, 75 Public ECDE teachers. Data was collected using questionnaires and interview schedules. Data collected was analyzed, mainly using descriptive statistics such as frequencies, percentages, means, sum and mode, with the aid of SPSS version 20. The analyzed data was presented using pie charts, tables, bar graphs and through description. The study was important to the Ministry of Education (MOE), particularly Special Need Education sub-sector to chat the way forward towards effective inclusion programs in ECDE centers. The study noted there is lack of overall ECDE centre plan on part of the administration for inclusion of learners with special needs. The study concluded that based on the results of the study undertaken, the research study recommends the following; The government should provide and improve the existing physical facilities to make sure they are easily accessible to all learners especially to the special pupils learning.
\end{abstract}

Keywords: Learning, Challenges, Inclusive, ECDE, Centres. 


\section{Introduction}

The idea of inclusive education depends on the way that all children and youngsters, notwithstanding different social, cultural and learning foundations, should have equivalent learning opportunities in a wide range of schools (Ahmmed, Sharma \& Deppeler, 2012). Persons with disabilities have faced discrimination and barriers that restricted them from participating in society on an equal basis with others every day (Ahmmedet al., 2012). Currently, there are many challenges or barriers to inclusive education all over the world (Muricho \& Chang'ach, 2013).

The World Health Organization (WHO) estimates that $10 \%$ of any population is person with disabilities and in addition approximately $85 \%$ of the world's children with disability below 15 years live in the developing countries (Ahmmedet al., 2012). Since time immemorial persons with disability (PWD) have faced many challenges that were in a large part a creation of the society. For instance, they used to throw away PWD children far into the bush so that they can die or be killed by wild animals. In other cases, these children were literally killed and buried very fast so that they are forgotten (Florian \& Linklater, 2010).

The families who had a history of disability in their genealogy were deemed cursed. Negative attitude towards disability has persisted for a long time (Ahmmedet al., 2012) and children with special needs and their families have been segregated and branded with abusive names like the deaf, the blind, the dumb or the crippled. The congregation of people with disability was either formal or non-formal. In the non-formal scenario, PWD were separated from others in the villages and in the formal setup, they were admitted into the so-called school of the PWD such as school of the deaf or school of the handicapped and so on (Gayle, Tewarie\& White, 2011).

There are many challenges regarding persons with disability (PWD) although most prevalent education conceptualizations have defined inclusion based on specific elements and features that allow learners age-appropriate placement to attend their local school. This according to Berlach and Chambers (2011) give room to philosophical structure for inclusive education in accordance with school-based and classroom-based examples. These philosophical underpinnings incorporate the accessibility of chance, acknowledgment of handicap or weakness, prevalent capacity and decent variety, and a nonappearance of predisposition, partiality, and disparity.

Interventions to resuscitate persons with disability started with formulation and implementation of laws conventions of treaties that touch on people with disability. Universal Declaration of Human Rights (UDHR), have somehow guaranteed protection of persons with disability (PWD), though protection clauses on persons with disability (PWD) have remained to a great extent "invisible', regularly side-lined in the correct discussion and helpless to appreciate the full scope of human rights. The tradition on the privileges of people with disabilities, which was adjusted in 2006 and went into power in 2008, flagged a "marching shift" from customary philanthropy arranged restorative based ways to deal with disability to one dependent on human right. According to "Kengelezahaki (2000) "disability is NOT "inability". The PWD if given opportunity can do various activities (Smith \& Tyler, 2011).

The Dakar framework for action (2000) recommended that governments should ensure that, by (2005) all children in spite of their disabilities should access to and finish free and essential 
primary education of good value. This was also cited by the Salamanca statement during the world conference on special needs education held in Salamanca Spain. According to Meynert (2014), each kid has extraordinary qualities, premiums, capacities and learning needs and those with special needs should approach customary schools which ought to oblige them with a youngster focused teaching method fit for addressing those needs.

The challenges are largely dependent on the stage of development and policies that guide its implementation. In a study done by Danner \& Fowler, (2015) in the USA, there are many challenges of inclusion into general and Montessori classrooms. Such challenges include those associated to school settings, teacher biases, parental involvement and collaboration between educators. On teacher biases, teachers are equipped for keeping the equalization in the classroom; notwithstanding, on the off chance that they are feeling negative towards inclusion, it can make a descending spiral (Fuchs, 2010). However, the findings were from developed country hence a research gap the same study to be done in developing countries especially Kenya.

\section{Statement of the Problem}

The introduction of Free Primary Education (FPE) in 2003 led to massive enrollments in public primary schools and ECDE centers. This led to enrolling all kinds of children to these free public primary schools with some of them having special needs. The pupils who have been enrolled come from various family backgrounds with some of them being challenged either through physical, hearing or visual impairment. The teachers get more and more challenges in these inclusive settings where less challenged children require specialized instruction that more often requires extra preparation on the part of the teacher and tolerance of the normal pupils who are with the challenged learners.

Despite the governments undying efforts over the years to curb the problem of exclusion among children with special educational needs, this problem has persistently been on the increase. Children with learning difficulties have not been adequately provided with the basic resources, physical facilities and equipment to cater for their special needs like their counterparts in regular schools. They continue to suffer disproportionately from whatever chronic problems affecting Kenya's education system. They are socially excluded from the mainstream settings by the nature of their learning disability. Most are taught in special schools for children with moderate and severe learning difficulties (Peter \& Nderitu, 2014). According to the ministry of education (2013), the government attaches great significance to education for all children including those with learning disabilities. Thus, the research study sought to investigate challenges affecting implementation of inclusive learning in Early Childhood Development Education in Eldoret East Sub-County, Uasin Gishu County Kenya.

\section{Objective of the Study}

The objective of the study was to find out the learning challenges to inclusive learning in an ECDE centres in Eldoret East Sub-County, Uasin Gishu County, Kenya. 


\section{Research Question}

i. What are the learning challenges to implementation of inclusive learning in an ECDE centres in Eldoret East Sub-County, Uasin Gishu County, Kenya?

\section{Theoretical Review}

The study was based on the Social Model of Disability Definition (Shakespeare, 2006). The theory traces its origins to the 1960s although its usage emerged in the United Kingdom in 1980s. The proponent of the theory was Oliver (1996). The Social Model of Disability Definition distinguishes the variables which bar physically tested and looks towards taking care of them. PWD don't confront disadvantage(s) in light of their impairments yet experience segregation in the manner in which we sort out society. This incorporates neglecting to make education, work, relaxation and open administrations available, neglecting to expel boundaries of presumption, generalization and preference and neglecting to prohibit unreasonable treatment in human lives. The social model looks past an individual's hindrance at all the important components that influence their capacity to be a full and equivalent member in the society (Donaldson \& Sapey, 2013). Subsequently PWD are relied upon to see their hindrance as their concern, something they should make the best of and acknowledge that there are numerous things they can't do therefore the study apply Medical Model of Disability' to help bring solution in ECDE centres (Oliver, 2017).

The social model of disability begins from an alternate point of view. It disregards how 'awful' an individual's hindrance is. Rather it builds up that everybody is equivalent and exhibits that it is society which erects hindrances that forestall handicapped individuals partaking and limits their play opportunities. Past studies look into way of organizing society that will change the way we treat learners and by extent people with disability. In the past children or learners with disabilities have been discriminated. The study bases this on discrimination of the PWD which has been there in the past.

The Social Model of Disability Definition theory is applicable to the study in the sense that it views the society who supports special needs students by facilitating their academic progress as the one who dictates the challenges faced by their teachers while in learning facilities. The concept of inclusive education in view all special needs learners as being capable of doing well as normal children and the society may as well subject them to educational parameters outcome. Therefore, any challenge that confronts them should be tackled. Thus, the research study seeks to investigate the challenges faced by ECDE teachers in the implementation of inclusive learning in Early Childhood Development Education (ECDE) in Eldoret East Sub-County, Uasin Gishu County, Kenya.

\section{Conceptual Framework}

Early Childhood Development Education (ECDE) programs have been up and running as usual, as annexed to every primary school. There are progressive efforts towards inclusion of learners with special needs into regular schools' system. The inclusion has attracted new ways of instruction in class as well as change in behavior of the teachers who implement the curriculum. There are 
many challenges to successful implementation of the inclusion program in ECDE education. It follows therefore that learning challenges comprise the dependent variable while inclusive learning was the independent variable since they determine the educational parameters.

Proper implementation and adoption of measures to handle the challenges may lead to access of education by all learners equally or provide effective learning environment or all learning expectations are met. However, there is intervening variable arising from the stakeholders to education like the government and other organizations. The stakeholders may play the center role by linking the independent and dependent variables through participation in some of the activities like resource allocation, training of teachers and implementation of strategies that focus on inclusive learning.

Independent Variables

Challenges

\section{Dependent Variable Implementation of Inclusive learning}

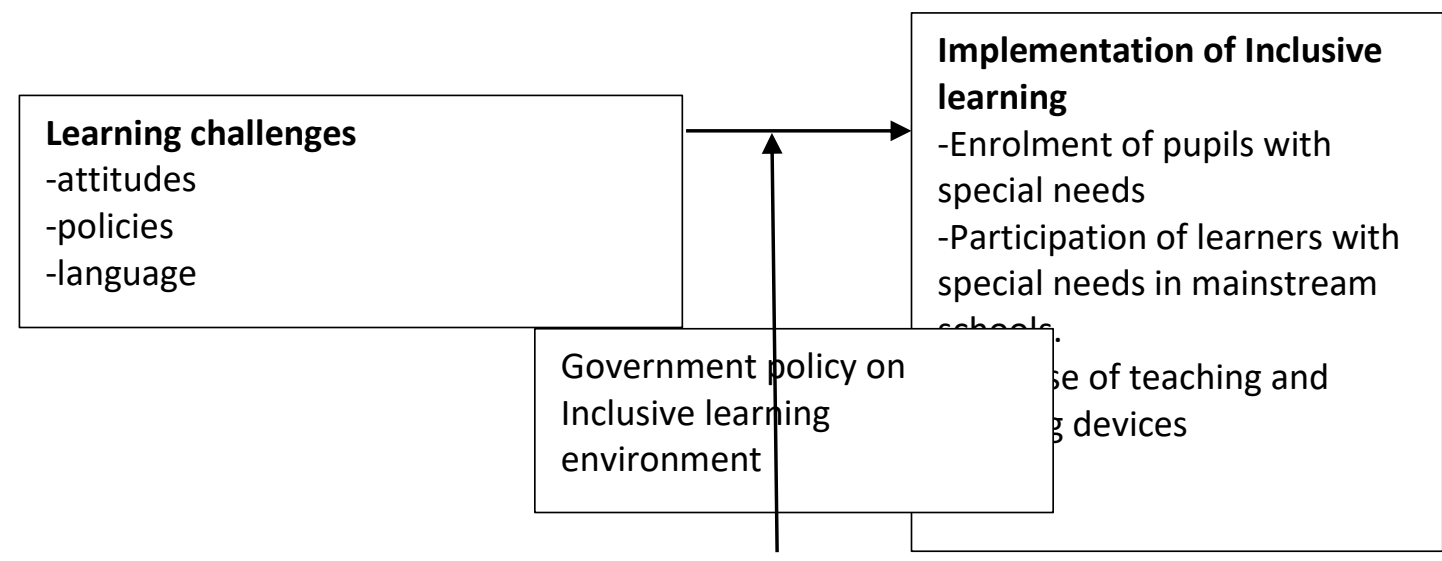

Fig.1.1 Illustration of Conceptual framework

Source: Researcher (2018)

\section{Empirical Review}

The literature reviewed examines the various existing literature allied to the objective of the study. The challenges in inclusive settings are enumerated and include among other teacher attitude, lack of understanding of inclusive it is apparent that they are nonexistent or inadequate as far as teaching of the physically or mentally challenged is concerned, not to mention poor teacher competency and skill to handle learners with special needs.

\section{Inclusive Education in Early Childhood Development Education}

There have been many definitions of Inclusive education. According to Ainscow (2005) Inclusive education refers to the act of inviting, esteeming, engaging and supporting different scholarly and social learning among students everything being equal. Comprehensive education is more than mainstreaming. Mainstreaming suggests that a student from a different specialized 
curriculum class visits the normal classroom for explicit, for the most part non-scholarly, subjects. Incorporation is an instructive procedure by which all students, incorporating those with disabilities, are taught together for all, or if nothing else most, of the school day (Rasmussen, Whitehead, Collier, \& Frías, 2008)

Inclusion is a theory of education dependent on the conviction that each individual has inherent appropriate to completely take an interest in the public arena. Inclusion suggests acknowledgment of contrasts. It accounts for the individual who might some way or another be avoided from the educational encounters that are key to each student's advancement. At the point when consideration is successfully executed, examine has exhibited scholastic and social advantages for all students, both the individuals who have exceptional needs just as common students. Friendships create, learners without special needs students are progressively keen to contrasts and students with disabilities are increasingly persuaded. Genuine acknowledgment of decent variety at last creates inside the school condition and is then conveyed into the home, work environment and society (National Down Syndrome Society) (National Down Syndrome Society, 2015). Inability to effectively understand inclusion in the education arena may lead to improper balancing in knowledge dissemination which may lead to impartiality.

Learners must start at the onset of establishing an institution for them to realize the full potential of inclusive setting, and it is also a basis for framework to support planning for all learners. This may include changing the contents, procedures, and result of the school and classroom educational modules to improve interest and commitment. Another guideline is taking a community approach, in which challenges to inclusive education is overcome through developing a more inclusive culture, which helps in establishing, supportive and respectful class climate. Kliewer \& Biklen (2001) asserts that regard accompanies love and seeing each child's abilities there is need to consider also the disabilities to ensure that they learn well in school.

The nearness of another vision, where communicating with students with handicaps turns out to be progressively agreeable, indicates guarantee for manners by which comprehensive teaching can be changed. The dispositions important to enable all students to pick up, incorporating those with inabilities, incorporate expanded mindfulness about qualities of students with disabilities and learning of the accepted procedures for teaching them (Cook et. al, 2008). The test is to advance and continue additionally tolerating dispositions toward the advantages of incorporating students with exceptionalities in the standard classroom in the expressions of Dallas Willard (2005).

\section{Challenges Faced in Implementing Inclusive Learning}

An inclusive classroom is where everyone feels included in classroom activities without looking at their disabilities, families, and the societies. It recognizes that every learner is unique and builds on their languages, cultures and interests and identifies and removes any challenges to achievements. Many aspects of learner's live (their experiences and needs) remain hidden unless we actively include them in class teaching and learning. Becoming more inclusive is a matter of thinking and talking, review and refining practice, and making attempts to do universal design learning Forlin (2013). Other challenges cited were lack of clear guidelines in the implementation 
of inclusive learning, inadequate of tools and skills, in identification and assessment, lack of reliable data on children with disabilities and a common curriculum that was tailored to meet special needs. When there are no clear guidelines, the effort to ensure there is inclusion were quite difficult or could have variation. This may make the teacher to apply that which is deemed best thereby posting more variations of the outcome.

Miles, (2000) report on learning is worried about expelling every one of the boundaries to learning and with the cooperation of all learners defenseless against prohibition and minimization. It is an indispensable system expected to empower learning accomplishment for all children. The approach is meant to address the shared objectives of diminishing and defeating all rejection from the human rights to education. It improves access, support and learning access in quality essential education for all.

Through practice and research, scholars and education stakeholders have attempted to identify challenges toward the success of inclusive education. A study by Mullins, (2010) recognized factors that influence the achievement of inclusive education. This is particularly crucial especially when it come to the implementers of curriculum in an inclusive setting. Without clear preparation of incorporation being spread out for the staff individuals before inclusive practices in an educational system start, and without an unmistakable, concise meaning of consideration, it is hard to take part in cooperative, group driven basic leadership that centers on all learners. Teachers may have different understanding of inclusion that can lead to variation of results. When teachers do not have uniformity of the concept inclusion and improper or totally lack of training on inclusion, then its implementation among the learners becomes a challenge. Samuels (2014) affirms the idea of improper inclusion by asserting that majority teachers are not well informed or trained when inclusion began because of little or no training at all. To him, full inclusion may not be implemented without making preparatory training because training makes things be done in a near uniformity version. There could be discrepancy among teachers about their roles in that the job of the customary education instructor verses the job of a specialized curriculum educator in an inclusive classroom is not clears due to lack of clarity of the term inclusion hence the discrepancy that leads to confusion

\section{Research Methodology \\ Research Design}

The study used descriptive survey design to investigate challenges affecting implementation of inclusive learning in Early Childhood Development Education in Eldoret East Sub-County, Uasin Gishu County Kenya. The design produces statistical information about aspects of education that interest policy makers, educators and other stakeholders. Descriptive survey is a method which is used in collecting information about peoples' attitudes, opinions, habits or any of the variety of education or social issues (Bryman, 2015) and since the study is concerned with analysis of challenges in inclusive learning, then the design is appropriate. This design includes arrays of interpretive techniques which seek to describe, decode, translate and come to terms with meaning (Cook, Edwards, Lacey, Guralnick, Soltis \& Allen, 2014). 
Kothari (2013), states that when the purpose of a study is accurate description of a situation or an association between variables, accuracy becomes a major consideration and a research design which minimizes bias and maximizes reliability of the evidence collected is considered a good design. The design minimizes bias by allowing the participants express their views and opinions. The design adopted enabled the research study to gather information from a wide range of respondents (for example Public ECDE teachers, Curriculum support officers and TSC Sub County Director of education) on the challenges affecting implementation of inclusive learning in Early Childhood Development Education in Eldoret East Sub-County, Uasin Gishu County Kenya.

\section{Study Area}

The study took place in Eldoret East Sub-County which is in Uasin Gishu County, Kenya. Uasin Gishu County is one of the 47 counties of Kenya, located in the former Rift Valley Province. The town of Eldoret is the county's largest population center as well as its administrative and commercial center. Uasin Gishu is located on a plateau and has a cool and temperate climate. It borders Trans-Nzoia County, Kenya.

The 2010 constitution of the Republic of Kenya outlines the existence of 47 Counties and Uasin Gishu County is one of them. The County has to its North is Trans Nzoia County and to its South is Kericho County. Eastwards is Elgeyo Marakwet County. Nandi County is to its South West and Kakamega County to the North West. The area of coverage is 3,345.2 Sq. Km (Kenya National Bureau of Statistics, Web). Uasin Gishu County is divided into six administrative units known as sub-counties that include Soy, Turbo, Eldoret East, Moiben, Kesses and Kapseret. The County has a population of 894,179 (Kenya National Census, 2009).

\section{Target Population}

A study population is a complete set of individuals' cases or objects with common observable characteristics (Scott \& Garner, 2013). The targeted group is conversant and has first-hand information which is valid for the study in order to achieve its objective. The accessible population of the study was parents, teachers, pupils, curriculum support officers and the Sub county director ECDE. The research study targeted respondents from public ECDE centers which included Public ECDE teachers and the TSC Sub County Director of education and the Curriculum support officers. The inclusive respondents were drawn from the 75 ECDE centers and are summarized in table 1.

Table 1: Target Population

\begin{tabular}{l}
\hline Population Entity \\
\hline Public ECDE teachers \\
Curriculum support officers \\
TSC Sub County Director of education \\
\hline TOTAL
\end{tabular}




\section{Sample Size}

A sample is a smaller group obtained from accessible population and each member has equal chance of being selected to be a sample (Best \& Kahn, 2016). It is also a definite part of a statistical population whose properties are studied to gain information about the whole (Kothari, 2011). In this study, the unit of statistical analysis comprises sampled Public ECDE teachers, Curriculum support officers and TSC Sub County Director of education in Eldoret East Sub County. After stratifying the target population to Public ECDE teachers, Curriculum support officers and Sub County Director ECDE; simple random sampling and purposive sampling technique was applied to developed stratus. The study applies $30 \%$ principle to Public ECDE teachers as suggested by Mugenda \& Mugenda (2012). The research study purposively sampled 85 respondents, including 1 TSC Sub County Director of education, and 9 Curriculum support officers' and 75 Public ECDE teachers from all the ECDE Centers. The sample size and sampling procedure is shown in table 2.

Table 2 Sample size

\begin{tabular}{lll}
\hline Population Entity & ing procedure & e \\
\hline Public ECDE teachers .3 & \\
Curriculum support officers & \\
TSC Sub County Director of & \\
\hline TOTAL
\end{tabular}

\section{Sampling Procedures}

According to Kothari, (2011) sampling is a procedure of selecting members of a research sample from accessible population which ensures that conclusion from the study can be generalized to study population. Since the ECDE centres fall under the county government; the study is narrowed down to sub-county government where the study focusses on ECDE centres in Eldoret East Sub-County. Simple random sampling was used to select 1 Public ECDE teacher from each ECDE center. Simple random sampling was used when collecting data from the public ECDE teachers. Simple random sampling is advantageous because all the targeted teachers have equal opportunity of being selected to participate in the study.

To select the public ECDE teacher's small pieces of paper was picked in each ECDE centre, names of all ECDE centers listed on a sheet of paper, folded and returned to the box. The pieces of folded papers in the box are well mixed and one picked. The same process is repeated until the number of ECDE centers needed to participate in the study in the ECDE centre was obtained. Purposive sampling techniques was appropriate to collect data from 9 Curriculum support officers and the TSC Sub County Director of education since purposive sampling method may prove to be effective when only limited numbers of people can serve as primary data sources due to the nature of research design and objective.

\section{Data Collection Instruments}

The research used both primary and secondary data collection techniques. The secondary techniques included relevant books on inclusive learning. Journals and articles presenting 
INTERNATIONAL JOURNAL OF ACADEMIC RESEARCH IN BUSINESS AND SOCIAL SCIENCES

Vol. 9, No. 11, November, 2019, E-ISSN: 2222-6990 @ 2019 HRMARS

analyzed challenges were also used. The primary data collection techniques included questionnaires and interview schedules as discussed below;

\section{Questionnaire}

Questionnaire entails carefully formulated and documented questions that are administered in the field to the selected population. Each item in the questionnaire is developed to address a specific objective, research questions or hypothesis of the study (Nutley, 2013). The research study used both structured (close-ended) questions and unstructured (open-ended) questions. The structured questions comprised the demographic information of the respondents and questions pertaining to the challenges affecting implementation of inclusive learning pertaining teachers. Questionnaires are economical to use in terms of time and money (Nutley, 2013). The unstructured/open ended questions permit a greater depth of response; simpler to formulate and the respondents may also give an insight into his/her feeling, background, hidden motivation and interests. Questionnaires were used to collect data from public ECDE Teachers. The study distributed 75 questionnaires to all the sampled public ECDE Teachers from the sub-county.

\section{Interview Schedule}

Interview method of collecting data involves presentation of oral-verbal stimuli and reply in terms of oral-verbal response (Kothari, 2013). Astalin, (2013) asserts that interview schedules are particularly suitable for intense investigation and they make it possible to obtain data required to meet specific objective of the study.

The study adopted face-to-face interviews. The main advantage of face-to-face interviewing is that it precludes any personal biases that might creep into the assessment process. Each interviewer will be picked up on different characteristics, strengths and weaknesses and together make a much fairer judgment.

The interview guide comprised of questions based on the research objective which was learning challenges to implementation of inclusive learning in ECDE centres in Eldoret East Sub-County, Uasin Gishu County, Kenya. They also yield higher response rates because it is unusual for a respondent to completely refuse to answer questions and the interviewer can get more information by using probing questions (Creswell, 2011).

In an interview, the interviewer clarified and elaborated the purposes of the research effectively as well as convinces respondents about the importance of the research adapt to the situation and get as much information as possible. In this study, the interview guide was administered to the director of ECDE at the county government office in order to find answers to the objective which was learning challenges to implementation of inclusive learning in ECDE centres in Eldoret East Sub-County, Uasin Gishu County, Kenya. The director is in charge of the county ECDE program and can give a wider understanding of the county and therefore may provide a dynamic view of the challenges. 


\section{Pilot Study}

A pilot study was carried out in two Early Childhood Development Education (ECDE) centres in a neighboring Eldoret West Sub-County before the actual research. This assisted the research study obtained various insights into the challenges which are not predictable before the actual research. It also helped the research study establish the reliability of the questionnaire, techniques pertinent to the study and the amount of time required for filling them out. The feedback obtained from the piloted ECDE centres helped the research study in revising the questionnaire to ensure that they cover the objective of the study adequately. Piloting ensured as much as possible that the items elicited and gave the kind of responses the research study intended to get and that they were acceptable in terms of their content.

\section{Validity and Reliability of Research Instruments}

Reliability is a measure of the degree to which a research instrument yields consistent results while validity is concerned with whether the instrument measures what it is supposed to measure (Mugenda \& Mugenda, 2012). In this research study, reliability and validity of the instruments used were tested.

\section{Validity}

Mugenda and Mugenda (2012) define validity as the degree to which results obtained from the analysis of data actually represent the phenomena under study. According to Kothari (2008), validity is the degree to which propositions or measures conform to established knowledge or truth. An attitude scale is considered valid, for example, to the extent that its results conform to other measures of possession of the attitude.

In this case, content validity of the research instruments was established in two ways. First, the research study discussed the items in the instrument with the university supervisors and lecturers allied with the research study' topic. Their feedback helped the research study to establish the validity of the research instruments. The feedback included suggestions, clarifications and other relevant input. These suggestions were used to make necessary changes to items in the questionnaires and interview schedule. This approach referred to as expert judgment method; it involves consulting one or more experts on the research study's' field. The experts provide estimates using their own methods and research experience. A researcher who uses expert judgment must ensure that it is effective since the estimates provided by people who are not actually doing the work are often less accurate. Therefore, to guarantee that good estimates are provided, one has to separate tasks into smaller ones and assign their estimations to people who have specific knowledge in specific task areas. When making estimations developers, testers and managers tend to de-emphasize tasks that they do not understand (Carlson, \& Herdman, 2012). Secondly, content validity of the research instruments was established through piloting. The responses of the piloted subjects were checked against the research objective. This justified why the contents of the instruments should be used. For a research instrument to be considered valid, 
the content selected and included in the questionnaire must be relevant to the variable being investigated.

\section{Reliability}

Reliability ensures that there is precision in which data is collected. To ascertain the reliability, the questionnaire was pre-tested through a pilot study. The reliability test was carried out on the questionnaire, where teachers were administered with the prepared questionnaire in a different sub county within the county. Responses were coded into SPSS version 17 and reliability coefficient, Cronbach's Alpha obtained. If the coefficient was at least 0.8 the reliability coefficient was accepted as a good measure. Coefficient was deemed fit if it is least 0.7 and comprises a criterion for a good reliability measure (Cooper \& Schlinder, 2014). In this study the reliability of the instruments was done keeping in mind the goal of survey descriptive research design. The research study will adjust the instruments by either including or dropping a few things with the end goal being improved reliability (Charalambous, Koulori, Vasilopoulos \& Roupa, 2018).

\section{Data Collection Procedures}

The research study will seek for an introductory letter from Kis University; school of Education. This letter was used to secure a permit from National Commission for Science, Technology and Innovation (NACOSTI). A research permit from the Ministry of Education Office was obtained. The research study also sought permission from the head teachers and teachers of the selected ECE Centres for the study to allow time for any adjustments. On the actual dates of the study, the research study visited selected ECDE centre to conduct the research. Interviews were conducted with the director of education to obtain in dept information pertaining to the objective.

\section{Data Analysis and Presentation}

Data analysis is the process of bringing order, structure and coding to raw data in order to draw conclusions. The research study used descriptive statistics; frequencies and percentages. This was done quantitatively with the aid of SPSS version 20 for windows. Interview schedule data was analyzed qualitatively under thematic areas defined by the objective. The raw data was grouped through coding and tabulation. Editing also is done to improve on the quality of the data. Presentation of data was by use of tables, pie charts and descriptions.

\section{Ethical Considerations}

The respondents were assured of confidentiality and thus the research study was open and honest when dealing with them. They were protected by keeping the information given confidential. Cited work was acknowledged in the study. The research study took responsibility for the conduct and consequences of the research by adhering to the time schedule agreed upon with the ECDE Centers' administration. The respondents also were assured of getting the feedback from the research if they need it after the study. The respondents who participated in this study were required to give a signed a voluntary informed consent prior to participation. The 
research study's explained and brief them on their rights and the expected benefits of the study. They got explanation about the purpose of the study and they accepted to participate and they signed consent form before participating. There was no any coercion or inducement to participate in the study. To ensure anonymity of participants serializing of the structured questionnaires was done. The participants were allowed to ask questions and answers were provided to their satisfaction. The research study's also asked the participants questions on the information provided to ascertain their comprehension about the study before they could sign the consent forms. Research tools were stored under locks and research information in computers under passwords

\section{Research Findings and Discussions \\ Response rate}

Out of 75 questionnaires sent out, 70 were dully filled and returned which translated to 93.3\%, response rate while 5 questionnaires were not filled representing $6.7 \%$ of the respondents. Despite the assurance given that the information to be given was to be treated confidentiality, some participants did not fill questionnaires perhaps because of personal reasons. According to According to Kothari (2011) a response rate of at least $80 \%$ is sufficient for a study to make generalization of the study findings. This therefore implied that findings achieved in this study were sufficient of generalization. Thus, in this study, the $93.3 \%$ were adequate for analysis.

\section{Pilot Study Results}

Piloted data were used to ascertain for validity and reliability of research instruments. The study used content validity to ascertain the validity of the research instruments. The study used experts to rate the relevance of the questions in the questionnaire. These experts included the research supervisors. The feedback from experts was used to improve the validity of the questionnaire. Reliability was done using Cronbach's Alpha where of more than 0.7 was taken as the cut off value for being acceptable which enhanced the identification of the dispensable variables. The internal consistency method provides a unique estimate of reliability for the given test administration. The results of the reliability tests were as shown in the Table 3 . The study findings indicated that values of learning challenges were 0.770 , value was above 0.7 implying research instruments used for data collection were reliable.

Table $3 \quad$ Reliability Test

\begin{tabular}{lll}
\hline Items & Cronbach's & N of Items \\
\hline Learning challenges & .770 & 8 \\
\hline
\end{tabular}

\section{Background Information}

As part of the general information, the research study requested the respondents (Public ECDE teachers) to indicate their gender, age bracket, level of education and type of disabilities. The 
analysis of these characteristics from the respondents was important since it assisted in getting accurate information on the ECDE centers where they work.

\section{Gender of Respondents}

The study intended to determine the gender distribution of Public ECDE teachers who were sampled for the research and the findings indicated that there were more females than males in all the schools included.

\section{Figure 2 Genders of the Respondents}

The results in Figure 2 of the total 70 ECDE teachers who participated in the study, 19(27\%) were

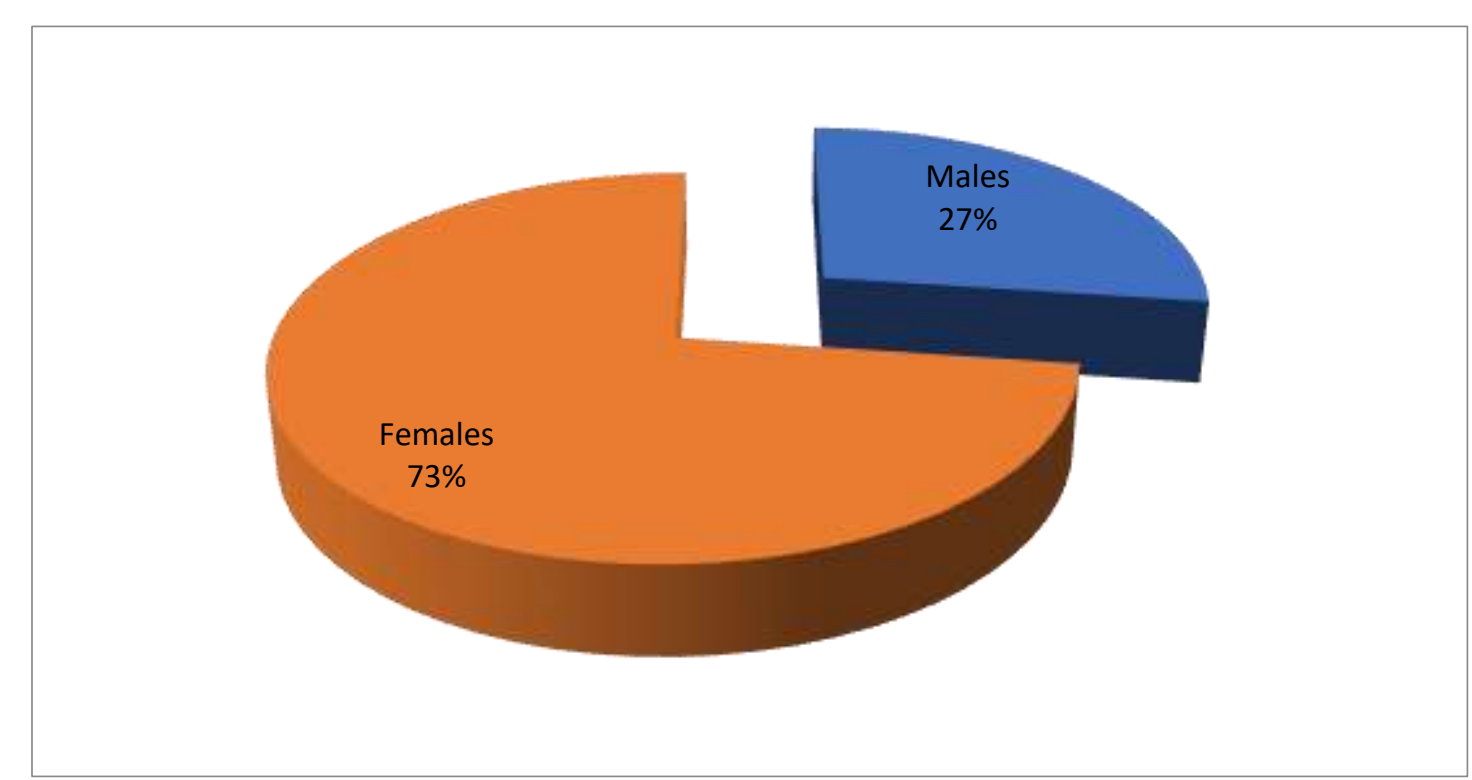

males

and

$51(73 \%)$

females.

This

indicated that most of the teachers who participated in the study and willingly gave valuable information were female. Despite this both genders were represented in the study to avoid gender biasness. However, there were at least one third of the total number of males in the mentioned positions and therefore adhering to Kenyan Constitution requirement.

\section{Age Brackets of the Respondents}

The study sought to find out the age brackets of the Public ECDE teachers. This was soughed in order to know which age category are teaching in ECDE centers. This was also to avoid the age biasness where all age bracket under employment participated in the study. 


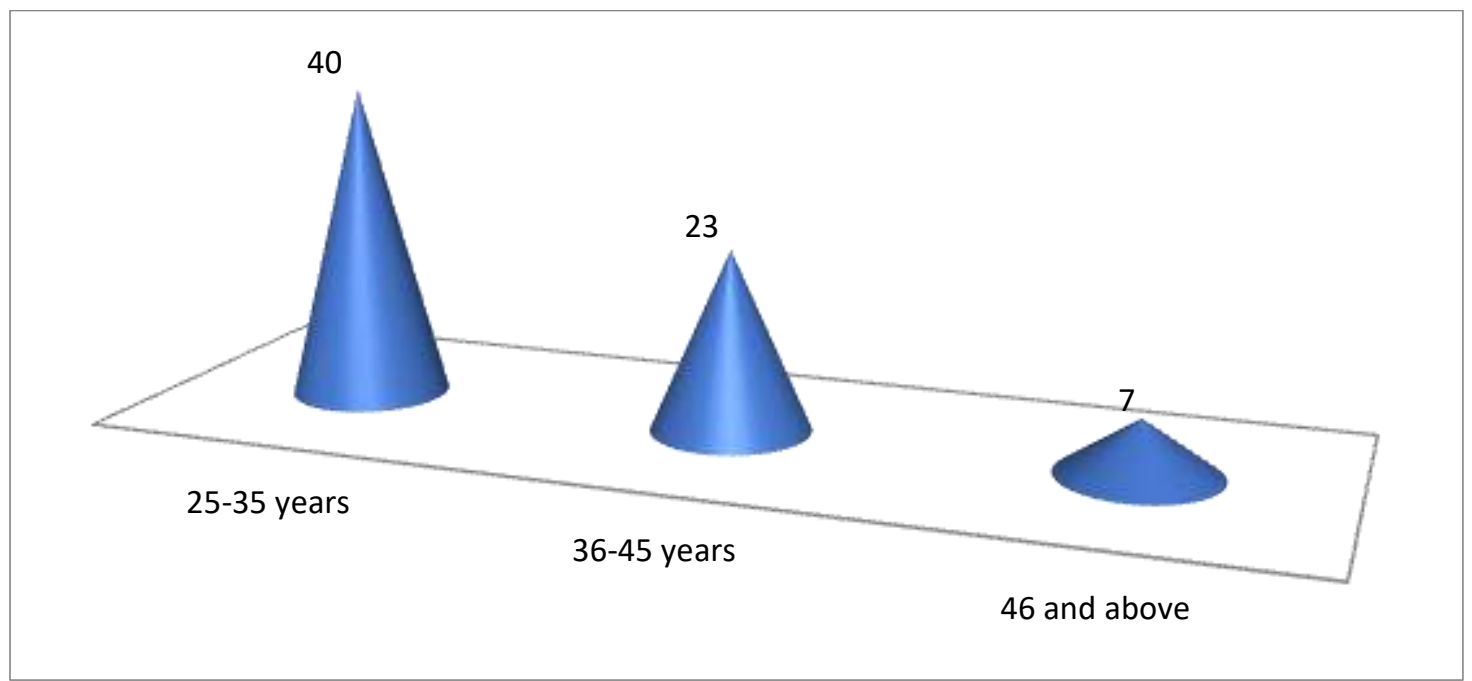

Figure 3 Age Brackets of the Respondents

The result of the Figure 3 showed that the more public ECDE teachers were of the age of 36-45 years at $40(56.5 \%)$ those of $25-35$ years at $23(32.9 \%)$ and lastly those of 46 years and above at $7(10 \%)$. The outcome established that the largest number of the subjects were those of 36-45 years. Okumbe (2001) argued that the older an employee is, the higher the performance and experience up to a certain age (age of 60) where performance would start declining. The finding therefore implies that the respondents were old and experienced enough to provide valuable responses that pertain the topic under the study.

\section{Highest level of Education}

The research study sought to find out the level of education of public ECDE teachers.

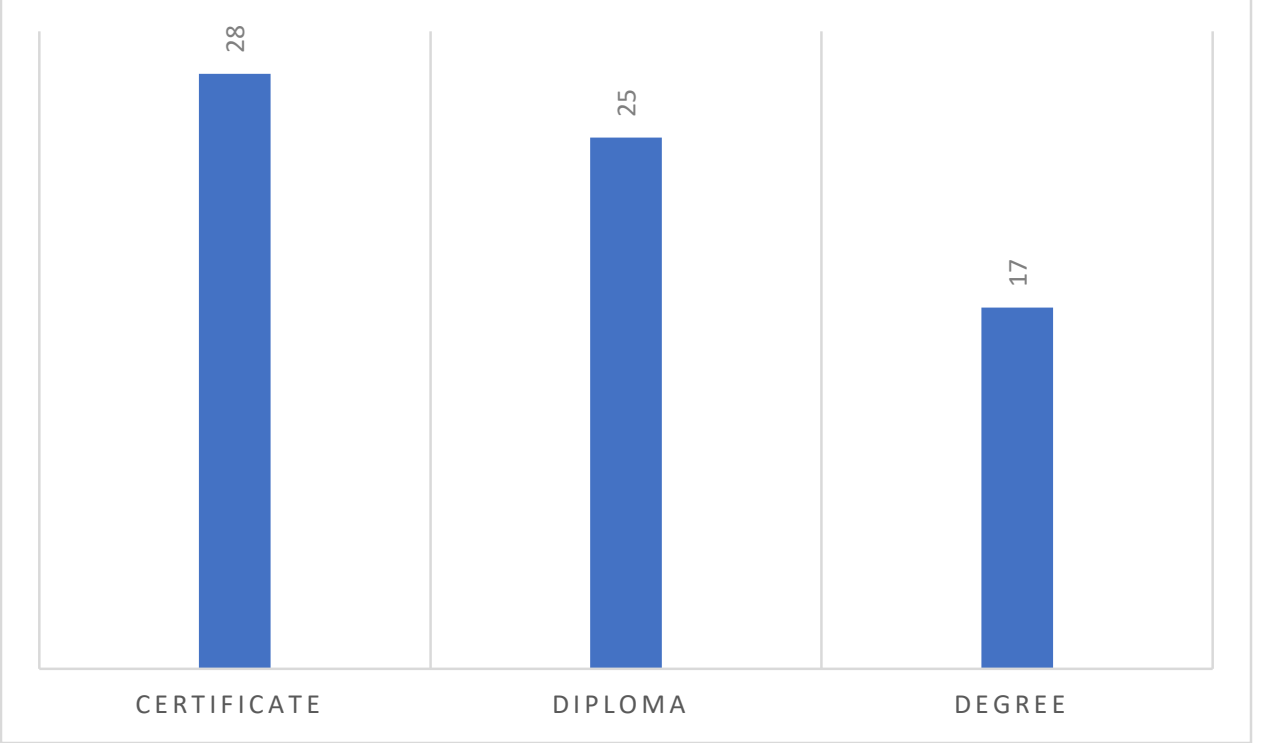




\section{Figure 4 Highest Level of Education}

According to the result (figure 4) the largest number of the public ECDE teachers were those who have attained certificate level of education $28(40 \%)$ followed by those with diploma at $25(35 \%)$ and those with degree at $17(25 \%)$. The study results established that the largest number of the public ECDE teachers was those with certificates. It also implied that the respondents could read and comprehend the questions in the questionnaire. The findings concur with (Clauser, et al, 2012) who argued that, if education level relates to professionalism then one can assume that the information provided is valid and reliable.

\section{Type of Disabilities}

The research study sought to find out the various types of disabilities in the sampled schools in the study locale of the pupils from public ECDE teachers.

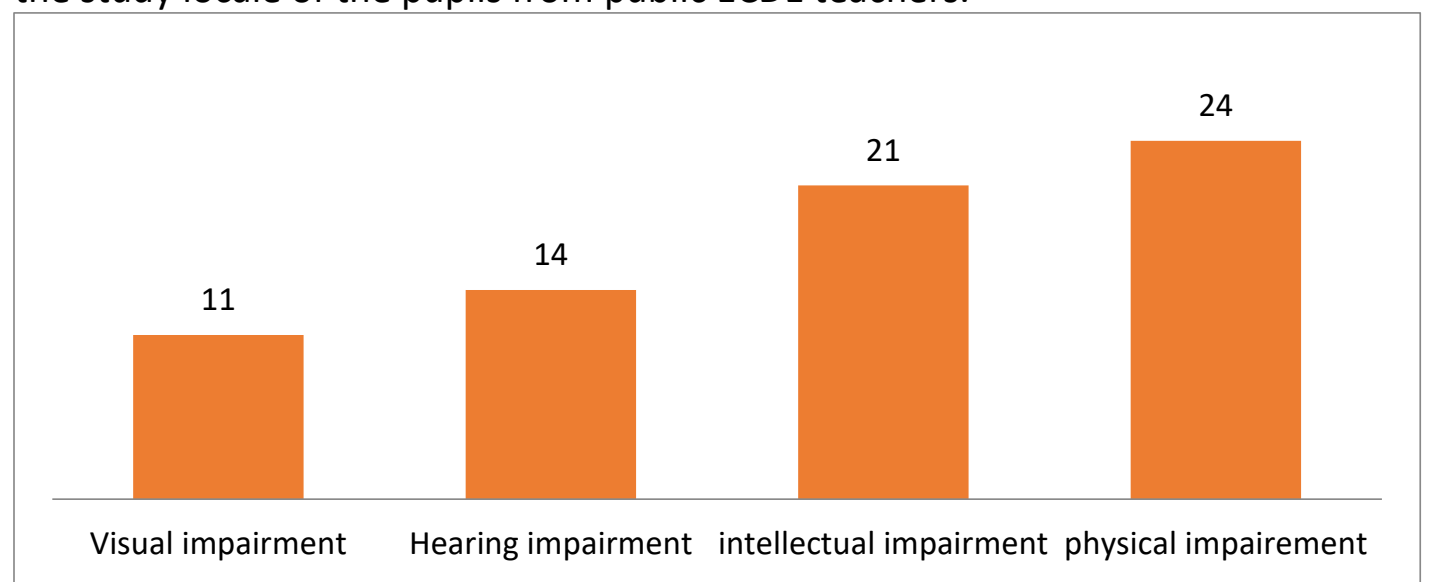

Figure 5 Type of Disabilities

The study established that the largest category of disability was physical impairment. The result in figure 5 established that most of the pupils at 24(34\%) had physical impairment followed by those with intellectual impairment at $21(30 \%)$ those with visual impairment at $11(16 \%)$ and finally those with hearing impairment at $14(20 \%)$. This would help the teacher to understand the needs of the special pupils in the school and handle them accordingly.

\section{Analysis of the Objective}

The descriptive statistics that were used in this study were frequencies and percentages. Frequencies were used to show the number of responses citing a particular responses while percentages were used to show the proportion of respondents giving a particular response out of the total number of respondents ( Saunders \& Lewis, 2000). In using a five-point Likert scale of 1-5 where; $1=$ strongly disagree, 2=Disagree, 3=Undecided, 4=Agreed, and 5= strongly agreed, a mean score less than 1.5 implied a complete disagreement to the corresponding statement. 
INTERNATIONAL JOURNAL OF ACADEMIC RESEARCH IN BUSINESS AND SOCIAL SCIENCES

Vol. 9, No. 11, November, 2019, E-ISSN: 2222-6990 @ 2019 HRMARS

\section{Learning Challenges to Inclusive Learning}

The study objective sought to analyze the learning challenges influencing implementation of inclusive learning in ECDE in Eldoret East sub-county Uasin Gishu County. Table 4.3 indicated the descriptive statistics achieved in regard to this objective from public ECDE teachers.

Table 5 Learning Challenges to Inclusive Learning

\begin{tabular}{|c|c|c|c|c|c|c|}
\hline Learning challenges & SA & $A$ & UD & $\mathrm{D}$ & SD & $\mathrm{N}$ \\
\hline $\begin{array}{l}\text { School management } \\
\text { resist accommodation } \\
\text { of students with } \\
\text { disabilities }\end{array}$ & $0(0 \%)$ & $6(9 \%)$ & $23(33 \%)$ & $31(44 \%)$ & $10(14 \%)$ & 70 \\
\hline $\begin{array}{l}\text { The school has a rigid } \\
\text { curriculum that does } \\
\text { not allow the use of } \\
\text { different teaching } \\
\text { methods }\end{array}$ & $14(20 \%)$ & $36(51 \%)$ & $17(24 \%)$ & $2(3 \%)$ & $1(1 \%)$ & 70 \\
\hline $\begin{array}{l}\text { Teachers who are not } \\
\text { trained to handle } \\
\text { special need children } \\
\text { are unwilling to work } \\
\text { with students with } \\
\text { disabilities }\end{array}$ & $0(0 \%)$ & $6(9 \%)$ & $18(26 \%)$ & $30(43 \%)$ & $16(23 \%)$ & 70 \\
\hline $\begin{array}{l}\text { The school does not } \\
\text { have the facilities to } \\
\text { accommodate students } \\
\text { with special needs }\end{array}$ & $12(17 \%)$ & $41(59 \%)$ & $17(24 \%)$ & $0(0 \%)$ & $0(0 \%)$ & 70 \\
\hline $\begin{array}{l}\text { Pupils with special } \\
\text { needs are faced with } \\
\text { classroom } \\
\text { infrastructure } \\
\text { challenges }\end{array}$ & $17(24 \%)$ & $37(53 \%)$ & $15(21 \%)$ & $1(2 \%)$ & $0(0 \%)$ & 70 \\
\hline $\begin{array}{l}\text { The school often lack } \\
\text { adequate facilities for } \\
\text { learning }\end{array}$ & $22(31 \%)$ & $35(50 \%)$ & $10(14 \%)$ & $1(2 \%)$ & $2(3 \%)$ & 70 \\
\hline $\begin{array}{l}\text { Students are unable to } \\
\text { afford basic necessities } \\
\text { and thus create barrier } \\
\text { for inclusive learning } \\
\text { process }\end{array}$ & $15(21 \%)$ & $33(47 \%)$ & $17(24 \%)$ & $4(6 \%)$ & $1(2 \%)$ & 70 \\
\hline
\end{tabular}


INTERNATIONAL JOURNAL OF ACADEMIC RESEARCH IN BUSINESS AND SOCIAL SCIENCES Vol. 9, No. 11, November, 2019, E-ISSN: 2222-6990 @ 2019 HRMARS

\begin{tabular}{lllllll} 
Policy makers don't & $0(0 \%)$ & $0(0 \%)$ & $21(30 \%)$ & $33(47 \%)$ & $16(23 \%)$ & 70 \\
understand or believe & & & & & \\
in inclusive education & & & & & \\
\hline
\end{tabular}

Source: (Survey data, 2019)

From the research findings in Table 5, the respondents disagreed 31(44\%) that; School management resist accommodation of students with disabilities. The respondents agreed $36(51 \%)$ with the statement that the school has a rigid curriculum that does not allow the use of different teaching methods the respondents disagreed 30(43\%) with the statement that Teachers who are not trained to handle special need children are unwilling to work with students with disabilities, the respondents agreed $41(59 \%)$ with the statement that The school does not have the facilities to accommodate students with special needs, the respondents agreed $37(53 \%)$ that; Pupils with special needs are faced with classroom infrastructure challenges; The school often lack adequate facilities for learning respondents agreed 35(50\%); Students are unable to afford basic necessities and thus create barrier for inclusive learning process the subjects agreed $33(47 \%)$ and that Many policy makers don't understand or believe in inclusive education and these leaders can stonewall efforts to make school policies more inclusive the subjects disagreed $33(47 \%)$.

The study results show that Learning challenges to inclusive learning were; lack of adequate facilities to accommodate students with special needs, new language used in teaching, lack of adequate facilities, unaffordable basic necessities which creates barrier for inclusive learning process and finally, lack of understanding by policies making makers in inclusive education.

The study findings agree with Avramis and Norwich (2002) who asserted that educational resources alludes to all components outside and inside the classroom that make teaching and learning increasingly successful, categorizing the resources according to the different impairment. Not only these resources enable to provide several activities but it also stimulates learners for better understanding, thus learning would be made real and meaningful.

The study findings were also in line with MOE (2009) which noted that there is deficient provision of proper teaching and learning materials for special needs education in light of the fact that the greater part of the materials accessible in the market are for the most part created for the ordinary educational module and normal learners and dependent on remote social setting. The restricted accessibility of curricular help materials likewise constrains the capacity of the teachers in special needs education to utilize an assortment of substance, teaching and learning exercises for compelling educational programs conveyance. A section from the assets distributed to each learner in Primary Schools/, those with special needs and disabilities motivate a best up capitation to cook for particular teaching/learning materials administrations and other assistive gadgets. This capitation has not been formalized as it is generally done on impromptu premise. The capitation is likewise lacking for buy to teaching/learning materials and provision of specialized services in these institutions.

The officials noted lack of adequate facilities to accommodate students with special needs. They also noted the new language used in teaching and lack of adequate facilities. Lack of qualified 
and propionate teachers were also the greatest barrier in implementation of inclusive learning and finally, lack of understanding by policies making makers in inclusive education. They suggested creation of mass awareness among all the stakeholders on the plight of learners with special needs and especially establish collaboration between teachers and parents.

One of curriculum support officers interviewed noted that; implementation of inclusive education has been hindered by deficient provision of proper teaching and learning materials for special needs education. This also has been worsening by few learning materials/resources available in the market".

Study findings concur with MOE (2009) report that there is deficient provision of proper teaching and learning materials for special needs education in light of the fact that the greater part of the materials accessible in the market are for the most part created for the ordinary educational module and normal learners and dependent on remote social setting. The restricted accessibility of curricular help materials likewise constrains the capacity of the teachers in special needs education to utilize an assortment of substance, teaching and learning exercises for compelling educational programs conveyance. The capitation is likewise lacking for buy to teaching/learning materials and provision of specialized services in these institutions (MOE, 2009).

\section{Summary, Conclusions and Recommendations Summary of the Findings Learning Challenges to Inclusive Learning}

The study objective sought to evaluate the learning challenges to inclusive learning in an ECDE centres in Eldoret East Sub-County, Uasin Gishu County, Kenya. The study results showed that learning challenges to inclusive learning were; lack of adequate facilities to accommodate students with special needs and new language used in teaching, lack of adequate facilities, qualified and propionate teachers, unaffordable basic necessities which creates barrier for inclusive learning process and finally, lack of understanding by policies making makers in inclusive education.

The study findings agreed with Avramis and Norwich (2002) who asserted that educational resources alludes to all components outside and inside the classroom that make teaching and learning increasingly successful, categorizing the resources according to the different impairment. Not only these resources enable to provide several activities but it also stimulates learners for better understanding, thus learning would be made real and meaningful.

The study findings are also in line with MOE (2009) there is deficient provision of proper teaching and learning materials for special needs education in light of the fact that the greater part of the materials accessible in the market are for the most part created for the ordinary educational module and normal learners and dependent on remote social setting. The restricted accessibility of curricular help materials likewise constrains the capacity of the teachers in special needs education to utilize an assortment of substance, teaching and learning exercises for compelling educational programs conveyance. A section from the assets distributed to each learner in Primary Schools/, those with special needs and disabilities motivate a best up capitation to cook for particular teaching/learning materials administrations and other assistive gadgets. This 
capitation has not been formalized as it is generally done on impromptu premise. The capitation is likewise lacking for buy to teaching/learning materials and provision of specialized services in these institutions.

\section{Conclusions of the Study}

The major problem encountered by teachers in their effort to implement the inclusive learning programme in schools is inadequate teaching-learning resources in the schools practicing inclusive education in Uasin Gishu county such as play facilities and instruments, assistive devices, space and an up to-date curriculum to guide the concerned teachers.

The was of great importance to teachers, learners with disabilities, parents and the Ministry of Education to understand challenges affecting implementation of inclusive learning in Early Childhood Development Education and how to handle them. The parents will be enlightening on the challenges experienced in the teaching and learning of children with disabilities hence coming up with strategies to ensure they support their children towards learning as normal children.

\section{Recommendations of the Study}

The government should come up with feasible education policies for both regular pupils and for those with learning difficulties. For the policies that are already inexistence, there is need to improve them bearing in mind that plight of inclusive learning learners. Such policies should be put into actual implementations at the grass not levels where most of the special needs cases are found. In some past policies have only existed on paper due to various constrains.

\section{Reference}

Ahmmed, M., Sharma, U., \& Deppeler, J. (2012). Variables affecting teachers' attitudes towards inclusive education in Bangladesh. Journal of Research in Special Educational Needs, 12(3), 132-140.

Ainscow, M. (2005). Developing inclusive education systems: what are the levers for change?. Journal of educational change, 6(2), 109-124.

Astalin, P. K. (2013). Qualitative research designs: A conceptual framework. International Journal of Social Science and Interdisciplinary Research, 2(1), 118-124.

Avramidis, E., \& Norwich, B. (2002). Teachers' attitudes towards integration/inclusion: a review of the literature. European journal of special needs education, 17(2), 129-147.

Berlach, R. G., \& Chambers, D. J. (2011). Interpreting inclusivity: An endeavour of great proportions. International Journal of Inclusive Education, 15(5), 529-539.

Bryman, A. (2015). Bryman, A. (2016). Social research methods. Oxford: Oxford University Press.

Burns, R. A., \& Burns, R. (2012). Business Research Methods and Statistics using SPSS. London: Sage Publications Ltd

Carlson, K. D., \& Herdman, A. O. (2012). Understanding the impact of convergent validity on research results. Organizational Research Methods, 15(1), 17-32. 
Charalambous, C., Koulori, A., Vasilopoulos, A., \& Roupa, Z. (2018). Evaluation of the Validity and Reliability of the Waterlow Pressure Ulcer Risk Assessment Scale. Medical Archives, 72(2), 141-147.

Clauser, B. E., Margolis, M. J., Holtman, M. C., Katsufrakis, P. J., \& Hawkins, R. E. (2012). Validity considerations in the assessment of professionalism. Advances in health sciences education, 17(2), 165-181.

Cook, J. A., Edwards, S. V., Lacey, E. A., Guralnick, R. P., Soltis, P. S., Soltis, D. E., ... \& Allen, J. M. (2014). Natural history collections as emerging resources for innovative education. BioScience, 64(8), 725-734.

Cooper, D., \& Schindler, S. (2014). Business Research Methods. New York: McGraw-Hill Irwin.

Creswell, J. W. (2011). Controversies in mixed methods research. The Sage handbook of qualitative research, 4(1), 269-284.

Danner, N., \& Fowler, S. (2015). Montessori and non-Montessori early childhood teachers' attitudes towards inclusion and access. Journal of Montessori Research, 1(1), 28-41.

Donaldson, G., \& Sapey, B. (2013). Rehabilitation and disabled people. A Handbook for Interprofessional Practice in the Human Services: Learning to Work Together, 171.

Florian, L., \& Linklater, H. (2010). Preparing teachers for inclusive education: using inclusive pedagogy to enhance teaching and learning for all. Cambridge journal of education, 40(4), 369-386.

Forlin, C. (2013). Changing paradigms and future directions for implementing inclusive education in developing countries. Asian Journal of Inclusive Education, 1(2), 19-31.

Fuchs, W. W. (2010). Examining teachers' perceived barriers associated with inclusion. SRATE Journal, 19(1), 30-34.

Gayle, D. J., Tewarie, B., \& White, J. A. Q. (2011). Governance in the twenty-first-century university: Approaches to effective leadership and strategic management: ASHE-ERIC higher education report. New Jersey: John Wiley \& Sons.

Kliewer, C., \& Biklen, D. (2001). "School's not really a place for reading": A research synthesis of the literate lives of students with severe disabilities. Journal of the Association for Persons with Severe Handicaps, 26(1), 1-12.

Kothari, C. (2011). Research Methodology; Methods and Techniques. New Delhi: New Age International Publishers

Kothari, C. R. (2013). Research Methodology: Methods and Techniques. New Delhi, India: New Age International Ltd. Publishers.

Meynert, M. J. (2014). Inclusive Education and Perceptions of Learning Facilitators of Children with Special Needs in a School in Sweden. International journal of special education, 29(2), 35-52.

Miles, S. (2000, October). Overcoming resource barriers: the challenge of implementing inclusive education in rural areas. In Symposium on Development Policy. Gustav Stresemann Institute, Bonn, Germany.

MOE. (2009). Special Needs Education Policy Draft. Nairobi: Government Printer. 
Mugenda, O. M., \&Mugenda, A. G. (2012). Research Methods: Quantitative and Qualitative Approaches. Nairobi: Acts Press.

Mullins, R. (2010). Do You See What I See?. Undergraduate Review, 6(1), 93-99.

Muricho, W. P., \& Chang'ach, J. K. (2013). Education reforms in Kenya for innovation. International Journal of Humanities and Social Science, 3(9), 123-145.

Nutley, S. (2013). Reflections on the mobilization of education research. The impact of research in education: An international perspective, 243-262.

Okumbe, J. A. (2001). Human Resource Management: An Educational Perspective: Educational Development and Research Bureau. Nairobi. Kenya.

Oliver, M. (1996). The social model in context. In Understanding disability. London: Palgrave.

Oliver, M. (2017). Defining impairment and disability: Issues at stake. In Disability and equality law. United Kingdom: Routledge.

Peter, M. N., \& Nderitu, M. N. (2014). Perceptions of teachers and head teachers on the effectiveness of inclusive education in public primary schools in Yatta Division Machakos County. Journal of Educational and Social Research, 4(1), 91-96.

Rasmussen, S. A., Whitehead, N., Collier, S. A., \& Frías, J. L. (2008). Setting a public health research agenda for Down syndrome: summary of a meeting sponsored by the Centers for Disease Control and Prevention and the National Down Syndrome Society. American Journal of Medical Genetics Part A, 146(23), 2998-3010.

Salmonsson, A. (2005). Disability is not Inability. Baseline Study towards inclusive Education in Blantyre, Balaka and Muchinga Districts in Malawi, Institute of Public Management.

Samuels, D. R. (2014). The culturally inclusive educator: Preparing for a multicultural world. Nairobi: Teachers College Press.

Saunders, M. L., \& Lewis, P. (2000). P. and Thornhill, A. (2009), Research Methods for Business Students. London: Financial Times Prentice Hall Inc.

Scott, G., \& Garner, R. (2013). Doing qualitative research: designs, methods, and techniques. Upper Saddle River: Pearson.

Shakespeare, T. (2006). The social model of disability. The disability studies reader, 2(1), 197-204.

Smith, D. D., \& Tyler, N. C. (2011). Effective inclusive education: Equipping education professionals with necessary skills and knowledge. Prospects, 41(3), 3-23 